\title{
Anti-Thrombin Unit
}

National Cancer Institute

\section{Source}

National Cancer Institute. Anti-Thrombin Unit. NCI Thesaurus. Code C70495.

A unit of anti-coagulation potency of antithrombin determined as the amount of antithrombin that neutralizes one unit of World Health Organization preparation 89/588 of thrombin. 